\title{
MATERIALS FOR SAFETY WEARING APPAREL
}

(Second Edition)

\author{
COMMERCIAL STANDARD CS129-47
}

Effective Date for New Production from July 21, 1947

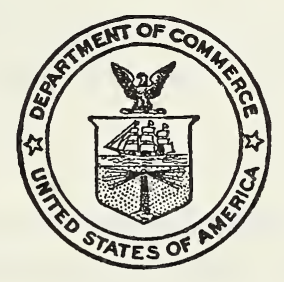

A RECORDED VOLUNTARY STANDARD OF THE TRADE

UNITED STATES DEPARTMENT OF COMMERCE

W. AVERELL HARRIMAN, Secretary 


\section{COMMERCIAL STANDARDS}

Commercial Standards are voluntary standards of the trade developed through concerted action of those directly concerned, and issued by the United States Department of Commerce upon written evidence of their acceptability to the trade. They are initiated by written request from a responsible element of business to the Division of Trade Standards of the National Bureau of Standards. The Division of Trade Standards of all concerned.

acts as a coordinating and fact-finding agency in ascertaining the desires

The Federal Government exercises no regulatory authority in the enforcement of Commercial Standards. In accepting a Commercial Standard, the producer, distributor, or user says in effect that he considers it a useful standard of practice, and plans to utilize it as far as practicable in his business, reserving the right to depart from the standard so long as no deception results from such departure. When reference to a Commercial Standard is made in contracts, labels, invoices, or advertising literature, however, the provisions of the standard are enforcible through usual legal channels as a part of the sales contract.

Organized in 1927, the Division of Trade Standards has assisted many industries in the development of Commercial Standards for a wide variety of commodities. A list of previously established Commercial Standards appear herein.

\section{COMMERCIAL STANDARD FOR MATERIALS FOR SAFETY WEARING APPAREL \\ (Second Edition)}

On April 30, 1943, a Recommended Commercial Standard for Materials for Safety Wearing Apparel was presented to those concerned for written acceptance. It was subsequently accepted by the trade, and promulgated by the United States Department of Commerce as Commercial Standard CS129-46.

On March 25, 1947, a revision recommended by the Standing Committee was circulated to producers, distributors, and users for written acceptance. Those concerned have since accepted and approved the Commercial Standard as shown herein.

Project Manager: L. R. Gilbert, Division of Trade Standards

National Bureau of Standards

Technical Advisers: Stewart J. Owen, Jr., Division of Codes and Specifications, National Bureau of Standards

W. D. Appel, Division of Organic and Fibrous Materials, National Bureau of Standards 


\section{COMMERCIAL STANDARD CS129-47}

\section{for}

\section{MATERIALS FOR SAFETY WEARING APPAREL (SECOND EDITION)}

\section{PURPOSE}

1. The purpose of this commercial standard is to (a) provide protection to the wearer of safety wearing apparel through the establishment of standard minimum quality requirements and methods of test for the material used in the manufacture of such apparel; (b) serve as a basis for fair competition between manufacturers; and (c) provide a foundation for guaranteeing the quality of the materials used in the manufacture of this product.

\section{SCOPE}

2. This commercial standard covers minimum quality requirements for the material used in the manufacture of safety wearing apparel, including :

(a) Asbestos fabrics.

(b) Cotton fabrics, flame-resistant.

(c) Leather.

(d) Woolen fabrics.

(e) Accessory materials.

3. This standard also covers methods of test and methods of labeling to certify or guarantee quality.

\section{MATERIAL SPECIFICATION}

\section{ASBESTOS FABRICS}

4. Asbestos fabrics.-These fabrics used in the general line of safety wearing apparel, including all kinds of hand protectors (including gloves and mittens, lined or unlined, plain or reinforced); all kinds of arm and leg protectors (including sleeves, leggings, spats, etc.); and all kinds of body protectors (including suits, pants, coats, capes, bibs, etc.), shall meet the following requirements:

(a) Grade of yarn.-Underwriters' grade asbestos content 80 percent minimum when tested according to methods of test approved by the National Bureau of Standards. (A. S. T. M. designation D299-42).

(b) Weave and size of yarn.-Herringbone 2 ply 14 cut; or basket (plain) weave 2 ply 10 cut.

(c) Minimum weight.-21/4 pounds per square yard.

(d) Breaking strength. - The fabric shall have a minimum breaking strength in conformity with table 1 , when tested by the grab method in accordance with procedure approved by the National Bureau of Standards. (Commercial Standard CS59-44). 
TABLE 1.-Breaking strength asbestos fabrics

\begin{tabular}{|c|c|c|}
\hline \multirow{2}{*}{ Weave } & \multicolumn{2}{|c|}{ Minimum breaking strength } \\
\hline & Warp & Filling \\
\hline Herringbone ................... & .165 & 70 \\
\hline Basket (plain) $\ldots \ldots \ldots \ldots \ldots \ldots$ & 145 & 55 \\
\hline
\end{tabular}

\section{COTTON FABRICS, FLAME-RESISTANT}

5. Heavy duty.-Flame-resistant cotton fabrics used in those items of safety clothing, including coats, pants, aprons, leggings, and heavy-duty sleeves, which are called upon to perform heavy duty service, shall have minimum quality base cloth as follows:

(a) Fabric.-Gray cotton duck, 12 ounces per linear yard in 29inch widths $(14.90 \mathrm{oz} / \mathrm{sq} \mathrm{yd})$.

(b) Weave.-Plain, two warp threads woven as one with single filling.

6. Light duty.-For those items of safety clothing such as coats, pants, sleeves, jumper suits and linings, which perform lighter hazards service, the minimum quality base cloth shall be:

(a) Fabric.-Gray cotton duck or suiting 8 ounces to 10 ounces per linear yard in 29-inch widths, (9.93 oz to $12.41 \mathrm{oz} / \mathrm{sq}$ yd).

(b) Weave.-Plain, with two warp threads woven as one, with single filling.

7. Construction.-The construction and strength requirements for the fabrics used in both the heavy duty and lighter duty garments shall be in accordance with table 2, when tested as indicated in Federal Specification CCC-T-19la. The breaking strength of the treated fabrics when tested by the grab method shall be not less than that required for the untreated cloth.

TABLE 2.-Construction and requirements of cotton fabrics

\begin{tabular}{|c|c|c|c|c|c|c|c|c|c|}
\hline \multirow{4}{*}{ Type of fabric } & \multicolumn{7}{|c|}{ Untreated (gray) } & \multicolumn{2}{|c|}{ Treated } \\
\hline & \multicolumn{2}{|c|}{ Nominal weight } & \multirow{3}{*}{$\begin{array}{c}\text { Minimum } \\
\text { weight } \\
\text { ounces per } \\
\text { square yard }\end{array}$} & \multirow{2}{*}{\multicolumn{2}{|c|}{$\begin{array}{l}\text { Minimum } \\
\text { thread count }\end{array}$}} & \multirow{2}{*}{\multicolumn{2}{|c|}{$\begin{array}{c}\text { Minimum } \\
\text { breaking } \\
\text { strength } \\
1 \text { by } 1 \text { by } 3 \\
\text { grab }\end{array}$}} & \multirow{2}{*}{\multicolumn{2}{|c|}{$\begin{array}{c}\text { Minimum } \\
\text { breaking } \\
\text { strength } \\
1 \text { by } 1 \text { by } 3 \\
\text { grab }\end{array}$}} \\
\hline & \multirow{2}{*}{$\begin{array}{l}\text { Ounces per } \\
\text { linear yard } \\
29 \text { inches } \\
\text { wide }\end{array}$} & \multirow{2}{*}{$\begin{array}{l}\text { Ounces per } \\
\text { square } \\
\text { yard }\end{array}$} & & & & & & & \\
\hline & & & & $W^{1}$ & F & W & $\mathrm{F}$ & W & F \\
\hline Duck or suiting. & 8 & 9.93 & 9.68 & 74 & 27 & 130 & 85 & 130 & 85 \\
\hline Duck or suiting. & 10 & 12.41 & 12.10 & 72 & 26 & 160 & 105 & 160 & 105 \\
\hline Duck. & 12 & 14.90 & 14.53 & 72 & 25 & 170 & 120 & 170 & 120 \\
\hline
\end{tabular}

1 Two threads woven as one.

8. Treatment.-The cotton fabrics indicated in table 2 shall be uniformly treated with a suitable nonpoisonous compound to produce a flame-resistant nonirritating cloth, no specimen of which when tested by the methods of test indicated in paragraph 16 shall continue flaming for 
more than 2 seconds after the burner flame is withdrawn. The average length of char of the specimens shall not be more than $31 / 2$ inches, and the maximum length of char for any one of the specimens shall not be more than $4 \frac{1}{2}$ inches.

\section{LEATHER}

9. Tannage.-All leather used in the manufacture of safety -wearing apparel shall be thoroughly chrome tanned, and shall contain not less than 5 percent nor more than 13 percent grease; and not less than 3 percent nor more than 5 percent chromic oxide when tested as indicated in paragraph 17.

10. Grading tolerance.- The leather shall be soft and pliable. It shall be free from skive cuts, and open grub holes, although well healed grub scars or brand marks are permitted. The use of shelly or middle splits is permitted only in the manufacture of gauntlets or cuffs.

\section{WOOLEN FABRICS}

11. Weight.-Woolen fabrics used in the manufacture of safety wearing apparel shall have a minimum weight of 20 ounces per linear yard in 54 -inch widths $(13.33 \mathrm{oz} / \mathrm{sq}$ yd).

12. Fiber content.-Woolen fabrics used in the manufacture of safety wearing apparel shall contain no fiber other than wool, reprocessed wool, reused wool, or a combination thereof, as described in the "Wool Products Labeling Act of 1939"' (Public No. 850-76th Congress).

\section{ACCESSORY MATERIALS}

13. Metal fasteners. - The metal fasteners used in the manufacture of safety wearing apparel shall be of such design as to permit ease of adjustment and removal of clothing, and shall be fully protected from corrosion by a tinning, japanning, or plating process when tested according to the method indicated in paragraph 18a.

13a. Buckles.-It is recommended that buckles, slides, loops, fasteners, hooks and eyes, eyelets and grommets shall be of sufficiently strong construction to meet the maximum safety requirements.

13b. Buttons, snap.-Brass spring type snap buttons with wide flanged studs of large size are recommended as the minimum standard for heavyduty safety wearing apparel. Ball-and-socket types of snap buttons are acceptable and recommended for service where the sturdier grip of the spring type is unnecessary.

13c. Rivets.-Tubular type rivets of a grade that will make a smooth clinch or a capped split type rivet are recommended as the minimum standard for safety wearing apparel.

14. Thread.-In the sewing necessary to the manufacture of safety wearing apparel, the lockstitch shall be used with at least four-cord unbleached-cotton thread (table 1, ticket No. 16, Federal Specification for Thread: Cotton V-T-276b), except that asbestos thread of suitable strength may be used for sewing asbestos cloth.

14a. Chain stitching and a lighter weight thread than that indicated in paragraph 14 may be used for linings.

\section{METHODS OF TEST COTTON FABRICS, FLAME-RESISTANT}

15. Specimens. For the tests on flame-resistant cotton fabrics, 10 specimens 2 by $12 \frac{1}{2}$ inches shall be cut with their long dimensions in 
the direction of the warp and 10 in the direction of the filling. Each lot of 10 shall be cut from at least 4 places in the sample.

16. Procedure.

16a. The specimens shall be suspended vertically from a clamp covering the upper $1 / 2$ inch of the length. To protect the specimen from drafts, the apparatus shall be enclosed in a sheet-metal shield 12 inches wide, 12 inches deep and 30 inches high, open at the top, and provided with a vertical sliding glass front. Sufficient room shall be left at the bottom of the front to allow manipulation of the gas burner used in igniting the specimen.

16b. The specimen shall be suspended with its lower end three-fourths of an inch above the top of a Bunsen or Tirrill gas burner, having a tube of three-eighths inch inside diameter, and with the air supply completely shut off, adjusted to give a luminous flame $11 / 2$ inches long. The flame is applied vertically near the middle of the width of the lower end of the specimen for 12 seconds, then withdrawn, and the duration of flaming in the specimen noted.

16c. The length of char shall then be determined. It is the distance from the end of the specimen which was exposed to the fire, to the end of the tear made lengthwise of the specimen through the center of the charred area in the following way. Hooks are inserted in the specimen, one on each side of the charred area one-fourth inch in from the adjacent outside edge. The weight specified in table 3 is attached to one hook and applied to the specimen gently, without impact, by raising the other hook. The specimen will tear through the charred-area until fabric strong enough to carry the load is reached.

TABLE 3.-Tearing weight of charred duck

\begin{tabular}{|c|c|}
\hline Weight per square yard of duck before treating & $\begin{array}{c}\text { Tearing weight for determining } \\
\text { charred length }\end{array}$ \\
\hline & Pound \\
\hline Up to 15 ounces............ & 0.5 \\
\hline 15.01 to 23 ounces............... & .75 \\
\hline
\end{tabular}

\section{LEATHER}

17. Grease and Chromic Oxide. In the event of disagreement between buyer and seller as to the methods of test to determine the amount of grease and chromic oxide in leather used in the manufacture of safety wearing apparel, the test methods approved by the National Bureau of Standards shall be used. (Federal Specification KK-A-606).

\section{ACCESSORY MATERIALS}

18. Metal Fasteners.

18a. Corrosion test. In the event of disagreement as to the method of test to determine the degree to which metal fasteners used in the manufacture of safety wearing apparel will withstand corrosion, the test methods approved by the National Bureau of Standards shall be used (Commercial Standard CS85-41). 


\section{LABELING}

19. When safety wearing apparel is guaranteed to comply with the commercial standard, it is recommended that the following form be used for guarantee on invoices and sales contracts:

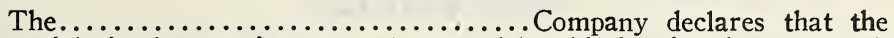
materials in the wearing apparel covered by this invoice (or contract) comply with all the applicable requirements of Commercial Standard CS129-47, for Materials for Safety Wearing Apparel, as issued by the National Bureau of Standards, United States Department of Commerce.

19a. It is also recommended that the minimum weight, and the type of weave (whether herringbone or basket-plain) of the asbestos fabric, and the type of flame-proof fabric (whether heavy or light duty), be indicated in catalogs and price lists and on invoices and sales contracts.

\section{EFFECTIVE DATE}

20. The standard is effective for new production from July $21,1947$.

\section{STANDING COMMITTEE}

21. The following individuals comprise the membership of the Standing Committee, which is to review, prior to circulation for acceptance, revisions proposed to keep the standard abreast of progress. Comment concerning the standard and suggestions for revision may be addressed to any member of the committee or to the Division of Trade Standards, which acts as secretary for the committee.

\section{E. L. WheELer, Chairman}

E. L. Wheeder, F. H. Wheeler Manufacturing Co., 224 West Huron Street, Chicago, Ill.

G. H. Schauwerer, American Optical Co., 1939 Thomas Street, South Bridge, Mass.

Don Kimbals, The Kimball Safety Products Co., 7314 Wade Park Avenue, Cleveland, Ohio.

I. W. Mirlard, Industrial Gloves Co., 777 Garfield Boulevard, Danville, Ill.

J. T. Grifris, Southern Asbestos Co., Charlotte, N. C.

C. A. Townes, A. D. Juilliard \& Company, Inc., (Aragon Mills Division), Aragon, Polk County, Ga.

AleXANDER MoRRISON, American Woolen Co., Inc., Lawrence, Mass.

Kenneth E. Bell, A. C. Lawrence Leather Co., Peabody, Mass.

J. E. Culliney, Bethlehem Steel Co., Bethlehem, Pa.

C. L. Wagner, Carnegie Illinois Steel Corporation, Duquesne, Pa.

H. S. Simpson, Caterpillar Tractor Co., Peoria, Ill.

Melbourne F. SinNARD, Safety Branch, Office of Industrial Relations, Navy Department, Washington 25, D. C.

ROBERT W. WEBSTER, Alternate, Research and Standards Branch, Bureau of Ships, Navy Department, Washington 25, D. C.

\section{HISTORY OF PROJECT}

22. On September 22, 1941, the Industrial Safety Equipment Association voted to request the cooperation of the National Bureau of Standards in establishing a commercial standard for materials for safety wearing apparel.

23. Following receipt of this request, copies of a proposed commercial standard were circulated to selected representatives of producer, distributor, and user organizations for advance comment.

24 . With the unqualified endorsement of a number of interested organizations, the recommended commercial standard for materials for safety wearing apparel was submitted to the entire trade for written acceptance on April 30,1943. Having received acceptances in writing estimated to 
represent a satisfactory majority, announcement was issued on March 5 , 1946, that the standard would become effective for new production from May 6, 1946.

\section{FIRST REVISION}

25. In February 1947, the Standing Committee recommended that the standard be revised in order to raise the quality of the asbestos from Commercial to Underwriters' grade, and increase the minimum breaking strength.

26. Accordingly, a revision of the standard was developed and circulated to those concerned for written acceptance. This was done on March 25 , 1947. Having received acceptances estimated to represent a satisfactory majority of production, and in the absence of valid opposition, the establishment of the standard was announced on May 20, 1947. 


\section{ACCEPTANCE OF COMMERCIAL STANDARD}

If acceptance has not previously been filed, this sheet properly filled in, signed, and returned will provide for the recording of your organization as an acceptor of this commercial standard.

\section{Date}

Division of Trade Standards, National Bureau of Standards, Washington 25, D. C.

Gentlemen :

We believe that the Commercial Standard CS129-47 constitutes a useful standard of practice, and we individually plan to utilize it as far as practicable in the

Production $^{1} \quad$ distribution $^{1} \quad$ purchase $^{1} \quad$ testing $^{1}$

of materials for safety wearing apparel.

We reserve the right to depart from it as we deem advisable.

We understand, of course, that only those articles which actually comply with the standard in all respects can be identified or labeled as conforming thereto.

Signature of authorized officer.

$$
\text { (In ink) }
$$

(Kindly typewrite or print the following lines)

Name and title of above officer

Organization

(Fill in exactly as it should be listed)

Street address

City, Zone, and State.

IUnderscore which one. Please see that separate acceptances are filed for all subsidiary companies and affiliates which should be listed separately as acceptors. In the case of related interests, trade associations, trade papers, etc., desiring to record their general support, the words "General Support" should be added after the signature. 


\section{TO THE ACCEPTOR}

The following statements answer the usual questions arising in connection with the acceptance and its significance:

1. Enforcement.-Commercial standards are commodity specifications voluntarily established by mutual consent of those concerned. They present a common basis of understanding between the producer, distributor, and consumer and should not be confused with any plan of governmental regulation or control. The United States Department of Commerce has no regulatory power in the enforcement of their provisions, but since they represent the will of the interested groups as a whole, their provisions through usage soon become established as trade customs, and are made effective through incorporation into sales contracts by means of labels, invoices, and the like.

2. The acceptor's responsibility.-The purpose of commercial standards is to establish for specific commodities, nationally recognized grades or consumer criteria and the benefits therefrom will be measurable in direct proportion to their general recognition and actual use. Instances will occur when it may be necessary to deviate from the standard and the signing of an acceptance does not preclude such departures; however, such signature indicates an intention to follow the commercial standard where practicable, in the production, distribution, or consumption of the article in question.

3. The Department's responsibility.-The major function performed by the Department of Commerce in the voluntary establishment of commercial standards on a Nation-wide basis is fourfold: first, to act as an unbiased coordinator to bring all interested parties together for the mutually satisfactory adjustment of trade standards; second, to supply such assistance and advice as past experience with similar programs may suggest; third, to canvass and record the extent of acceptances and adherence to the standard on the part of producers, distributors, and users; and fourth, after acceptance, to publish and promulgate the standard for the information and guidance of buyers and sellers of the commodity.

4. Announcement and promulgation.-When the standard has been endorsed by a satisfactory majority of production or consumption in the absence of active valid opposition, the success of the project is announced. If, however, in the opinion of the Standing Committee or the Department of Commerce, the support of any standard is inadequate, the right is reserved to withhold promulgation and publication. 


\section{$\operatorname{CS} 129-47$}

\section{ACCEPTORS}

27. The organizations listed below have individually accepted this standard for use as far as practicable in the production, distribution, testing or purchase of materials for safety wearing apparel. In accepting the standard, they reserved the right to depart therefrom as they individually deem advisable. It is expected that articles which actually comply with the requirements of this standard in all respects will be regularly identified or labeled as conforming thereto, and that purchasers will require such specific evidence of conformity.

\section{ASSOCIATIONS \\ (General Support)}

American Foundrymens Association, Chicago, III.

Cotton Textile Institute, Inc., The, New York N. Y.

Dairymen's League Co-Operative Association, Inc., New York, N. Y.

Industrial Safety Equipment Association, New York, N. Y.

National Association of Leather Glove Manufacturers, Inc., Gloversville, $\mathrm{N}$ Y.

National Association of Wool Manufacturers, New York, N. Y.

Webbing Manufacturers Institute, New London, Conn.

\section{FIRMS}

Aball Asbestos Co., Newark, N. J.

Acme Safety Products Co., Akron, Ohio.

Alabama By Products Corp., Birmingham, Ala. Alabama Dry Dock Shipbuilding Co., Mobile. Ala.

Allegheny Ludlum Steel Corp., Brackenridge, $\mathrm{Pa}$

Allied Weld-Craft, Inc., Indianapolis, Ind.

American Forging \& Socket Co., Pontiac, Mich.

American LaFrance-Foamite Corp., Elmira, N. Y.

American Optical Co., Southbridge, Mass.

American Radiator \& Standard Sanitary Corp., Pitîsburgh, $\mathrm{Pa}$

American Rolling Mill Co., The, Middletown, Ohio.

American Viscose Corp., New York, N. Y. (general support).

American Woolen Co., New York, N. Y.

Arkansas Naturai Gas Corp., Shreveport, La.

Armstrong Cork Co., Lancaster, Pa.

Bagley \& Sewall Co., The, Watertown, N. Y.

Bakelite Corp., Bound Brook, N. J.

Baldwin Locomotive Works, The, Eddystone, $\mathrm{Pa}$.

Ball Brothers Co., Muncie, Ind.

Balmar Corp., The, Baltimore, Md.

Banner Iron Works, St. Louis, Mo.

Bartlett \& Snow Co., The C. O., Cleveland, Ohio.

Bausch \& Lomb Optical Co., Rochester, N. Y. Beach Manufacturing Co.. Charlotte, Mich.

Beaird Co.. Ltd., J. B., Shreveport, La.

Bell Co., M. A., St. Louis, Mo.

Bethlehem Steel Co., Bethlehem, $\mathrm{Pa}_{\mathbf{a}}$.

Rlaw-Knox Co., Pittsburgh, Pa.

Boston Woven Hose \& Rubber Co., Cambridge, Mass.

Botwinik Bros., Inc., Hamden, New Haven, Conn.

Bover-Campbell Co. The, Detroit, Mich:

Bullard Co., The. Bridgeport, Conn.

Bullard Co., E. D., San Francisco, Calif.
Bunker Hill \& Sullivan Mining \& Concentrating Co., Kellogg, Idaho.

Burke \& Co., Inc., J. Franklin, New York,

$\mathrm{N}, \mathrm{Y}$

Carey Machinery \& Supply Co., Baltimore, Md.

Carey Manufacturing Co., The Philip, Lock. land, Cincinnati, Ohio.

Carolina Asbestos Co., Davidson, N. C.

Catalin Corp. of America, Fords, N. J.

Caterpillar Tractor Co., E. Peoria, III.

Central Iron \& Steel Co. Harrisburg, Pa.

Charlottesville Woolen Mills, . Charlottesville, $\mathrm{Va}$.

Chicago Brick Co., Chicago, III.

Chicago Eye Shield Co., Chicago, Ill.

Chicago Hardware Foundry, N. Chicago, Ill

Cleveland Cliffs Iron Co., Ishpeming, Mich.

Colorado Fuel \& Iron Corp., Pueblo, Colo.

Combustion Engineering Co., Inc., Hedges. Walsh-Weidner Division, Chattanooga, Tenn.

Consolidated Iron Steel Manufacturing Co., The, Cleveland, Ohio.

Continental Steel Corp., Kokomo, Ind.

Corduroy Rubber Co., Grand Rapids, Mich

Cutter, Wood \& Sanderson Co., Cambridge, Mass.

Davenport Besler Corp., Davenport, Iowa.

Dennis Mitchell Industries, W. Philadelphia, $\mathrm{Pa}$.

Detroit Testing Laboratory, The, Detroit, Mich.

Devoe \& Raynolds Co., Inc., Malden, Mass.

Dollin Corp., Irvington, N. J

Donald Sales \& Manufacturing Co., Milwaukee, Wis.

Douglas Aircraft Co., Inc., Santa Monica, Calif.

Dresser Manufacturing Division, Dresser Industries, Inc., Bradford, $\mathrm{Pa}$.

Eagle-Ottawa Leather Co., Grand Haven, Mich.

Eastman Kodak Co., Rochester, N. Y.

Eclipse Glass Co.. Thomaston, Conn.

Edge Moor Iron Works, Inc., Edge Moor, Del.

Electro Refractories \& Alloys Corp., Lackawanna, N. Y.

Ensco Derrick \& Equipment Co., Los Angeles, Calif. (general support).

Enterprise Coal Mining Co.. Garrett, Pa.

Fairchild Aircraft Corp., Hagerstown, M̀d.

Farnam Co., F. D., Chicago, IIl.

Federal Belting \& Asbestos Co., Ltd., The, Toronto, Ontario, Canada.

Fenton Foundry Supply Co., The, Dayton, Ohio.

Fibre \& Metal Products, Inc., Downey, Calif.

Follansbee Steel Corp.. Pittsburgh. Pa.

Foote Mineral Co., Philadelphia, $\mathrm{Pa}$.

Fort Pitt Bridge Works, Canonsburg, Pa.

Fulton Iron Works Co., St. Louis, Mo.

Gates-Mills, Inc. Johnstown, N. Y.

Gatke Corp., Chicago, Ill.

Gay Brothers Co., Cavendish. Vt.

Gebhardt Co., A. L., Milwaukee, Wis. 
General Electric Co., Schenectady, N. Y. General Iron Works Co., Denver, Colo. General Machine Works, York, Pa.

Genter Co., C. D., Chattanooga, Tenn.

Geuder Paeschke \& Frey Co., Milwaukee, Wis. Gladding, McBean \& Co.. San Francisco, Calif. Glascote Products, Inc., Cleveland, Ohio.

Great Lakes Carbon Corp., Chicago, Ill. Great Lakes Steel Corp., Ecorse, Mich. Greene, Tweed \& Co., N. Wales, Pa. Haddock Mining Co., Wilkes-Barre, $\mathrm{Pa}$.

Hansell-Elcock Co., Ċhicago. Ill.

Hatch Textile Research, New York, N. Y.

Heller Brothers Co., Newark, N. J.

Hewitt Robins, Inc., Robins Conveyors Divi sion. Passaic, N. J.'

Hobart Brothers Co., The, Troy, Ohio

House \& Sons, Inc., Chas. W., Unionville, Conn.

Houze Convex Glass Co., L. J., Point Marion, $\mathrm{Pa}$.

Hudson Bay Mining \& Smelting Co., Ltd., Flin Flon, Manitoba, Canada.

Hudson Valley Fuel Corp., Troy, N. Y.

Huyck \& Sons, F. C., Albany, N. Y.

Industrial By-Products \& Research Co., Philadelphia, $\mathrm{Pa}$.

Industrial Gloves Co., Danville, Ill.

Ingersoll Steel Division, Borg.Warner Corp. Chicago, Ill.

Inland Steel Co., E. Chicago, Ind.

Interstate Machinery \& Supply Co., Omaha, Nebr.

Irvington Smelting \& Refining Works, Irving ton, N. J.

Jessopp Steel Co., Washington, $\mathrm{Pa}$

Jewel Paint \& Varnish Co., Chicago, I11.

Jewell Ridge Coal Corp., Jewell Ridge, Tazewell County, Va.

Jones \& Naudin Cंo., Gloversville, N. Y.

Kelly Springfield Tire Co., The, Cumberland, Md.

Keystone Steel \& Wire Co., Peoria, Ill.

Kimball Safety Products Co., Cleveland, Ohio.

Laclede Gas Light Co., The. St. Louis, Mo.

Lake Union Drydock Co., Seattle, Wash.

Lancaster Lens Co., The, Lancaster, Ohio.

Lawrence Leather Ċo., A. C., Peabody, Mass.

Lehigh Navigation Coal Co., Inc., Lansford, $\mathrm{Pa}$.

Lewis Foundry \& Machine Division, BlawKnox Co., Pittsburgh, $\mathrm{Pa}$.

Lewyt Corp., Brooklyn, N. Y

Link-Belt Co., Chicago, Iil.

Lockheed Aircraft Corp., Burbank. Calif.

Lummus Co., The, New York, N.Y.

MacAlpin Coal Co. Charleston, W. Va.

Mackintosh Hemphili Co.. S. S. Pittsburgh, Pa.

Macy \& Co., Inc., R. H., New York, N. Y.

Malleable Iron Fittings Co., Branford, Conn.

Mallory \& Co.. Inc., P. R., Indianapolis, Ind.

Mark \& Co., Clayton, Evanston. Ill.

Martin Co., Glenn L., Middle River, Md.

McKay Co., The. Pittsburgh, Pa.

Merchandise Research Laboratories, Philadelphia, $\mathrm{Pa}$.

Mesta Machine Co., Pittsburgh, $\mathrm{Pa}$.

M: chigan, University of, Ann Arbor, Mich.

Midwest Piping \& Supply Co., Inc., St. Louis, Mo.

Milwaukee Gas Light Co., Milwaukee, Wis.

Mine Safety Appliances Co.. Pittsburgh. $\mathrm{Pa}$.

Mine \& Smelter Supply Co., The, Denver, Colo.

Minneapolis-Honeywell Regulator Co., Minneanolis, Minn.

Minneapolis Moline Power Implement Co., Minneapolis, Minn.

Minnesota Power \& Light Co., Duluth, Minn.

Monsanto Chemical Co., Merrimac Division, Everett, Mass,

Montgomery Ward, Chicago, Ill.

Moore Dry Dock Co., Oakland, Calif.

Morrisdale Coal Mining Co., Morrisdale, $\mathrm{Pa}$.

Mount Vernon Woodberry Mills, Inc., New York. N. Y.

Nashville Bridge Co., Nashville, Tenn.

National Iron Works, San Diego, Calif.

National Refining Co.. The, Cleveland, Ohio.

New York Power \& Light Corp., Albany, N. Y.
Nilson Machine Co., The A. H., Bridgeport, Conn.

North American Aviation, Inc., Los Angeles, Calif.

Oat \& Sons, Inc., Joseph, Philadelphia, $\mathrm{Pa}$.

Ohio Oil Co., The, Findlay, Ohio.

Olsen Testing Machine Co., Tinius, Philadelphia, $\mathrm{Pa}$.

Olympic Glove Co., Inc., The, New York, N. Y.

Pacific Car \& Foundry Co., Renton, Wash.

Pacific Gas \& Electric Co., San Francisco, Calif.

Parsons Co., The, Newton, Iowa.

Patterson Foundry \& Machine Co., The, East Liverpool, Ohio.

Penn Anthracite Collieries Co., Scranton; $\mathrm{Pa}$. Penn Rivet \& Machine Co., Philadelphia, Pa.

Pennsylvania, Commonwealth of, Department of Property \& Supplies, Bureau of Standards, Harrisburg, $\mathrm{Pa}$.

Peoples Gas Light \& Coke Co., The, Chicago, IIl.

Pfaudler Co., The, Rochester, N. Y.

Phillips Doup \& Co., Lindenhurst, $\dot{N}$. Y.

Piper Aircraft Corp., Lock Haven, $\mathrm{Pa}$.

Pittsburgh Midway Coal Mining Co., Pittsburg, Kans.

Pittsburgh Screw \& Bolt Corp., Pittsburgh, $\mathrm{Pa}$.

Pittsburgh Testing Laboratory, Pittsburgh, Pa.

Porter Co., Inc., H. K., Pittsburgh, Pa.

Potter \& Johnston Machine Co., Pawtucket, R. I.

Powhatan Mining Co., The, Powhatan Point, Ohio.

Protective Equipment, Inc., Chicago, Ill.

Pulmosan Safety Equipment Corp., Brooklyn, N. Y.

Pulverizing Machinery Co., Summit, N. J.

Raniville Co., F., Grand Rapids, Mich.

Raybestos-Manhattan, Inc., General Asbestos \& Rubber Division, N. Charleston, S. C., and Manheim, $\mathrm{Pa}$.

Red Parrot Coal Co., Prenter, W. Va.

Riddell Corp., W. A., Bucyrus, Ohio.

Robinson Clay Product Co., The, Akron, Ohio. Ryan Aeronautical Co., San Diego, Calif.

Safety Clothing \& Equipment Co., Cleveland, Ohio.

Safety First Supply Co., Pittsburgh, Pa.

Sharon Steel Corp., Sharon, $\mathrm{Pa}$.

Shenango Furnace Co., Pittsburgh, $\mathrm{Pa}$.

Simmons Machine Tool Corp., Albany, N. Y.

Sinclair Refining Co., E. Chicago, Ind.

Sligo Iron Store Co., St. Louis, Mo.

Smith Co., S. Morgan, York, Pa.

Southern Asbestos Co.. Charlotte, N. C.

Southport Paint Co., Savannah, Ga.

Spring Canyon Coal' Co., Salt Lake City, Utah.

Sta-Warm Electric Co., Ravenna. Ohio.

Standard Asbestos Co., New York. N. Y

Standard Asbestos Manufacturing Co., Chicago, Ili.

Standard Coal, Inc., Salt Lake City, Utah. Standard Safety Equipment Co., Chicago Ill.

Star I.eather Co., Inc., Gloversville, N. Y.

Stearns Coal \& Lumber Co., Stearns, Ky.

Steelcote Manufacturing Co., St. Louis, Mo.

Stolper Steel Products Corp., Milwaukee, Wis.

Stone Supply Co., L. R., Kansas City, Kans.

Stupp Bros. Bridge \& Iron Co. St. Louis. Mo.

Sun Shipbuilding \& Dry Dock Co., Chester, Pa.

Sutton-Garten Co., Indianapolis, Ind.

Talbot Mills. Inc.. N. Billerica Mass.

Texas Co. The, New York, N. Y.

Thomas Machine Manufacturing Co., Pitts. burgh, $\mathrm{Pa}$.

Tillman \& Co.. Tohn, Long Beach, Calif

Tintic-Standard Mining Co., Salt Lake City, Utah.

Todd Shinvards Corp., Los Angeles Division, San Pedro, Calif.

Turner Halsey Co., New York, N. Y.

Union Asbestos \& Rubber Co. Cicero, Ill.

United States Safety Service Co., Kansas City, Mo.

United States Testing Co., Inc., Hoboken, N. $\mathrm{T}$.

Vanadium-Alloys Steel Co., Colonial Steel Di. vision, Monaca, $\mathrm{Pa}$. 
Victor Manufacturing \& Gasket Co., Chicago, Wood Steel Co., Alan, Conshohocken, Pa. IIl.

Woolley, W. P., Portland, Oreg.

Welin Davit \& Boat Corp., Perth Amboy, N. J. Westinghouse Electric Corp., E. Pittsburgh, $\mathrm{Pa}$.

Wyatt Coal Co., Charleston, W: Va.
Wyckoff Steel Co., Ambridge, Pa.

Westmoreland Mining Co., Blairsville, $\mathrm{Pa}$.

Wheeler Manufacturing Co., F. H., Chicago, Ill.

oungstown Safety Supply Co., Youngstown, Ohin.

Zaremba Co., Buffalo, N. Y. UNITED STATES GOVERNMENT

Wheeling Steel Corp., Wheeling, W. Va.

Whitlock Manufacturing Co., The, Elmwood, Conn.

Wiegand Co., Edwin L., Pittsburgh, Pa.

Wiggins Manufacturing Co., Seattle, Wash.

Williams, White \& Co., Moline, IIl.

iculture, U. S. Department of, Division of Purchase, Sales \& Traffic, Washington, D. C. Federal Works Agency, Public Buildings Administration, Washington, D. C.

Labor, U. S. Department of, Washington, D. C.

Williamson Heater Co., The, Cincinnati, Ohio.
Wisconsin Electric Power Co., Milwaukee, Wis. 
CS No.

0-40. Commercial standards and their value to business (third edition).

1-42. Clinical thermomeiers (third edition).

2-30. Mopsticks.

3-40. Stoddard solvent (third edition).

4-29. Staple porcelain (all-clay) plumbing fixtures.

5-46. Pipe nipples; brass, copper, steel and wrought-iron (second edition).

6-31. Wrought-iron pipe nipples (second edition). Superseded by CS5-46.

7-29. Standard weight malleable iron or steel screwed unions.

8-41. Gage blanks (third edition).

9-33. Builders' template hardware (second edition).

10-29. Brass pipe nipples. Superseded by CS5-46.

11-41. Moisture regains of cotton yarns (second edition).

12-40. Fuel oils (fifth edition).

13-44. Dress patterns (fourth edition).

14-43. Boys' button-on waists, shirts, junior and sport shirts (made from woven fabrics) (third edition).

15-46. Men's pajama sizes (made from woven fabrics) (third edition).

16-29. Wall paper.

17-42. Diamond core drill fittings (third edition)

18-29. Hickory golf shafts.

19-32. Foundry patterns of wood (second edition).

20-42. Staple vitreous china plumbing fixtures (third edition).

21-39. Interchangeable ground-glass joints, stopcocks, and stoppers (fourth edition).

22-40. Builders' hardware (nontemplate) (second edition).

23-30. Feldspar.

24-43. Screw threads and tap-drill sizes.

25-30. Special screw threads. Superseded by $\mathrm{CS} 24-43$.

26-30. Aromatic red cedar closet lining.

27-36. Mirrors (second edition).

28-46. Cotton fabric tents, tarpaulins and covers (second edition).

29-31. Staple seats for water-closet bowls.

30-31. Colors for sanitary ware.

31-38. Wood shingles (fourth edition).

32-31. Cotton cloth for rubber and pyroxylin coating.

33-43. Knit underwear (exclusive of rayon) (second edition).

34-31. Bag, case, and strap leather.

35-47. Hardwood plywood (third edition).

36-33. Fourdrinier wire cloth (second edition).

37-31. Steel bone plates and screws.

38-32. Hospital rubber sheeting.

39-37. Wool and part wool blankets (second edition). (Withdrawn as commercial standard, July 14, 1941).

40-32. Surgeons' rubber gloves.

41-32. Surgeons' latex gloves.

42-43. Structural fiber insulating board (third edition).

43-32. Grading of sulphonated oils.

44-32. Apple wraps.

45-46. Douglas fir plywood (sixth edition)

46-40. Hosiery lengths and sizes (third edition).
CS No.

Item

47-34. Marking of gold-filled and rolled-goldplate articles other than watchcases.

48-40. Domestic burners for Pennsylvania anthracite (underfeed type) (second edition).

49-34. Chip board, laminated chip board and miscellaneous boards for bookbinding purposes.

50-34. Binders board for bookbinding and other purposes.

51-35. Marking articles made of silver in combination with gold.

52-35. Mohair pile fabrics ( 100 percent mohair plain velvet, 100 percent mohair plain frieze, and 50 percent mohair plain frieze).

53-35. Colors and finishes for cast stone.

54-35. Mattresses for hospitals.

55-35. Mattresses for institutions.

56-41. Oak flooring (second edition).

$57-40$. Book cloths, buckrams, and impreg. nated fabrics for bookbinding purposes except library bindings (second edition).

58-36. Woven elastic fabrics for use in overalls (overall elastic webbing).

59-44. Textiles - testing and reporting (fourth edition).

60-36. Hardwood dimension lumber.

61-37. Wood-slat venetian blinds.

62-38. Colors for kitchen accessories.

63-38. Colors for bathroom accessories.

64-37. Walnut veneers.

65-43. Methods of analysis and of reporting fiber composition of textile products (second edition).

66-38. Marking of articles made wholly or in part of rlatinum.

67-38. Marking articles made of karat gold.

68-38. Liquid hypochlorite disinfectant, deodorant, and germicide.

69-38. Pine oil disinfectant.

70-41. Phenolic disinfectant (emulsifying type) (second edition) (published with CS71-41).

71-41. Phenolic disinfectant (soluble type) (second edition) (published with CS70-41).

72-38. Household insecticide (liquid spray type).

73-45. Old growth Douglas fir standard stock doors (third edition).

74-39. Solid hardwood wall paneling.

75-42. Automatic mechanical draft oil burn ers designed for domestic installations (second edition).

76-39. Hardwood interior trim and molding. 77-40. Sanitary cast iron enameled ware.

78-40. Ground-and polished lenses for sun glasses (second edition) (published with CS79-40).

79-40. Blown, drawn, and dropped lenses for sun glasses (second edition) (published with CS78-40).

80-41. Electric direction signal systems other than semaphore type for commercial and other vehicles subject to special motor vehicle laws (after market).

81-41. Adverse-weather lamps for vehicles (after market).

82-41. Inner-controlled spotlamps for vehicles (after market). 
CS No.

83-41. Clearance, marker, and identification lamps for vehicles (after market).

84-41. Electric tail lamps for vehicles (after market)

85-41. Electric license-plate lamps for vehicles (after market).

86-41. Electric stop lamps for vehicles (after market)

87-41. Red electi ic warning lanterns.

88-41. Liquid burning flares.

89-40. Hardwood stair treads and risers.

90- - (Reserved for power shovels and cranes).

91-41. Factory-fitted Douglas fir entrance doors.

92-41. Cedar, cypress and redwood tank stock lumber.

93-41. Portable electric drills (exclusive of high frequency).

94-41. Calking lead.

95-41. Lead pipe.

96-41. Lead traps and bends.

97-42. Electric supplementary driving and passing lamps for vehicles (after market).

98-42. Artists' oil paints.

99-42. Gas floor furnaces-gravity circulating type.

100-44. Porcelain-enameled steel utensils (second edition).

101-43. Flue-connected oil-burning space heaters equipped with vaporizing pot-type burners.

102- - (Reserved for Diesel and fuel-oil engines).

103-42. Cotton and rayon velour (jacquard and plain).

104-46. Warmair furnaces equipped with vaporizing pot-type oil burners ( $\mathrm{sec}$ ond edition).

105-43. Mineral wool; loose, granulated, or felted form, in low-temperature installations.

106-44. Boys' pajama sizes (woven fabrics) (second edition).

107-45. Commercial electric-refrigeration condensing units (second edition).

108-43. Treading automobile and truck tires. 109-44. Solid-fuel-burning forced-air furnaces. 110-43. Tire repairs-vulcanized (passenger truck, and bus tires)
CS No.

Item

111-43. Earthenware (vitreous-glazed) plumbing fixtures.

112-43. Homogeneous fiber wallboard.

113-44. Oil-burning floor furnaces equipped with vaporizing pot-type burners.

114-43. Hospital sheeting for mattress protection.

115-44. Porcelain-enameled tanks for domestic use.

116-44. Bituminized-fibre drain and sewer pipe.

117-44. Mineral wool; blankets, blocks, insulating cement, and pipe insulation for heated industrial equipment.

118-44. Marking of jewelry and novelties of

(E) 119-45. ${ }^{\text {silver }}$ Dial indicators (for linear measurements).

120-46. Standard stock ponderosa pine doors (second edition).

121-45. Women's slip sizes (woven fabrics).

122-45. Western hemlock plywood.

123-45. Grading of diamond powder.

(E) 124-45.1 Master disks.

125-45. Prefabricated homes.

126-45. Tank mounted air compressors.

127-45. Self-contained mechanically refrigerated drinking water coolers.

128-45. Men's sport shirt sizes-woven fabrics (other than those marked with regular neckband sizes).

129-47. Materials for safety wearing apparel (second edition).

130-46. Color materials for art education in schools.

131-46. Industrial mineral wool products, all types-testing and reporting.

132-46. Hardware cloth.

133-46. Woven wire netting.

134-46. Cast aluminum cooking utensils (metal composition).

135-46. Men's shirt sizes (exclusive of work shirts).

136-46. Blankets for Hospitals (wool, and wool and cotton.)

137-46. Size measurements for men's and boys' shorts (woven fabrics).

138-47. Insect wire screening.

1.39-47. Work gloves.

140-47. Convectors: testing and rating.

141-47. Sine bars, blocks, plates and fixtures

NoticE.-Those interested in commercial standards with a view toward accepting them as a basis of everyday practice may secure copies of the above standards, while the supply lasts, by addressing the Division of Trade Standards, National Bureau of Standards, Washington 25, D. C.

'Where "(E)" precedes the CS - number, it indicates an emergency commercial standard, drafted under war conditions with a view toward early revision. 
